\title{
ANALISIS PROGRAM PENGEMBANGAN KAPASITAS KELEMBAGAAN MASYARAKAT DESA: Suatu Studi Pada Program Pengembangan Masyarakat Miskin di Perdesaan
}

\author{
Heru Nurasa \\ Staf Pengajar Prodi Administrasi Publik Fakultas Ilmu Sosial \\ dan ilmu Politik Universitas Padjadjaran \\ Email:hnurasa@yahoo.com
}

\begin{abstract}
ABSTRAK
Studi ini dilakukan untuk mengetahui pengembangan kapasitas kelembagaan masyarakat desa untuk menyelenggarakan masalah publik dilingkungan desa secara mandiri dan berkelanjutan. Di masa lalu, kelembagaan masyarakat desa dengan sistem gotong royong telah terbukti berperan signifikan dalam menyelesaikan persoalan publiknya secara mandiri. Program pemerintah, melalui Program Nasional Pemberdayaan Masyarakat Perdesaan, bert ujuan mengembalikan kemandirian masyarakat desa tersebut dengan memberikan stimulan melalui pemberian bantuan dana dan pendampingan/fasilitasi program.

Metodologi yang digunakan adalah gabungan dari metode analisis isi (content analysis) dari berbagai dokumen, peraturan, dan hasil studi terdahulu dengan memperhatikan setiap periode kebijakan yang diberlakukan, dan metode kualitatif melalui pengamatan dan wawancara dengan informan kunci untuk manangkap "makna" dari setiap kebijakan pemerintah.

Hasil studi menunjukan bahwa Program Nasional Pemberdayaan Masyarakat di Perdesaan telah mampu mengaktualisasikan partisipasi masyarakat sebagai sumberdaya lokal yang potensial untuk menyelesaikan permasalahan publiknya secara mandiri dan berkelanjutan. Sistem nilai program, yaitu kompetisi, telah mampu merubah pola pikir dan pola perilaku masyarakat dan aparat terhadap program dari pola charity menuju pola pemberdayaan.
\end{abstract}

Kata kunci: Pemberdayaan, Kapasitas Kelembagaan, Partisipasi. 


\section{ABSTRACT}

This study was conducted to determine the development of the institutional capacity of rural communities to organize public problems within the village level. In the past, the village community institutions with "gotong royong" (mutual assisstant) has been proven to play a significant role in solving public problems independently. Government programs, through the National Program for Community Empowerment in Rural Areas, aims to restore the independence of the communities by providing stimulus through the provision of financial assistance and facilitation program.

The methodology used is a combination of content analysis method of various documents, regulation, and the results of previous studies, and qualitative methods through observation and interviews with key informants to get the "meaning" of any government policy,

The study results showed that the National Program for Community Empowerment in Rural Areas has been able to actualize people's participation as a local resource to solve problems independently and sustainability. Value program system, namely competition, has been able to change the mindset and behavior patterns of society and also the apparatus of the program from the pattern of charity towards the empowerment pattern.

Keywords: Empowerment, Institutional Capacity, Participation.

\section{PENDAHULUAN}

Keberadaan kelembagaan masyarakat di masa lalu ditandai dengan semangat gotong royong, bahkan untuk memenuhi kebutuhan warga pribadi sekalipun. Misalnya, seorang warga yang sedang membangun rumah, akan dibantu secara gotong royong oleh warga lainnya. Semangat ini juga berlangsung dalam kegiatan masyarakat untuk urusan publik, seperti membangun jalan setapak, pos yandu, dan urusan publik laninnya. Kondisi ini juga menyebabkan tugas dan tanggungjawab pemerintah desa dalam penyelenggaraan urusan publik menjadi lebih mudah dilakukan, ketika kapasitas kelembagaan masyarakat desa dapat memberikan konstribusi aktif untuk menyelesaikan persoalan publik di level desa. Argumen ini, kemudian menjadi dasar bagi pemerintah untuk mengeluarkan berbagai kebijakan penguatan kelembagaan masyarakat desa, agar masyarakat desa dapat memecahkan persoalaan publiknya secara mandiri dan berkelanjutan. Fakta inilah yang menarik perhatian peneliti untuk mengkaji berbagai kebijakan 
pemerintah dalam memperkuat kapasitas kelembagaan masyarakat desa.

Dalam tataran empiris, arti pentingnya kebijakan penguatan kelembagaan masyarakat desa ini juga adalah bahwa sebagian besar warga negera Indonesia tinggal di pedesaan. Berdasarkan data Ditjen PMD, Departemen Dalam Negeri RI bahwa jumlah desa di Indonesia saat ini sebanyak 68.988 desa, atau sekitar $70 \%$ penduduk tinggal di kawasan pedesaan. Gambaran tersebut memberikan arti bahwa penguatan penyelenggaraan pemerintahan dan pembangunan di wilayah pedesaan merupakan suatu keniscayaan, melalui pemberian otonomi kepada (masyarakat) desa dengan memperhatikan asal usul desa, adat istiadat dan budayanya. Dalam sejarah perjalanannya, otonomi desa di Indonesia telah mengalami pasang surut, baik dilihat dari aspek perkembangan kebijakan yang selamaini diberlakukan ataupun dari segi dinamika (kelembagaan) masyarakat desa itu sendiri dalam berotonomi.

Potret kelembagaan mayarakat di pedesaan yang ada saat ini pun, kemudian tidak terlepas dari pengaruh berbagai program pemberdayaan ("intervensi") dari pemerintah. Selama beberapa dekade, utamanya pada masa Orde Baru, misi pembangunan diwarnai oleh logika pertumbuhan ekonomi dengan kata kunci produksi dan produktivitas. Logika pertumbuhan ini sangat kuat mewarnai program pemberdayaan. Tujuannya secara instant dapat merubah kinerja (ekonomi) pedesaan, dengan memperkenalkan instutsi (formal) secara transplantatif. ${ }^{12}$ Institusi formal bentukan proyek ini dapat terus eksis selama masa proyek berlangsung. Hal ini karena program (proyek) pemberdayaan menawarkan stimulan berupa sumberdaya (dana dan dampingan). Dalam pendekatan resource dependence bahwa eksistensi institusi sangat berhubungan erat dengan setting sumberdaya yang tersedia pada lingkungan eksternal. Sumberdaya yang ditawarkan proyek merupakan stimulan bagi ("elit") masyarakat untuk secara instant menerima lembaga (formal) baru. Namun, sumberdaya melalui program tersebut bersifat semu, karena perolehannya tidak terkait dengan prestasi instutusi. Berbeda dengan

12. Sebagaimana dijelaskan terdahulu bahwa institusi komunitas merupakan produk dari proses pembelajaran dan penyepakatan norma, nilai dan standar berperilaku dan pola-pola bertindak dalam kurun waktu yang lama dan terus menerus. Instutsi formal dibentuk dengan berlandaskan aturan yang disepakati bersama. Sementara itu, program pemberdayaan dari pemerintah secara langsung memperkenalkan organisasi formal, tetapi kehilangan spiritnya karena terlepas dari instutusi komunitas yang berlaku. 
sumberdaya alamiah, memerlukan persaingan untuk perolehannya. Akibatnya program ini, justru menjadi tidak kondusif terhadap penguatan institusi komunitas itu sendiri. Lembaga baru bentukan proyek pun tidak mampu bertahan, karena tidak mempunyai basis yang kuat untuk dijadikan sebagai nilai, norma ataupun standar bagi aturan bertindak dan berperilaku suatu komunitas. Berbeda dengan kelembagaan masyarakat tradisional, karena dibentuk dan disepakati oleh mereka sendiri, maka sistem aturan yang berlaku pun akan merasa dimiliki oleh mereka, sehingga mengakar kuat dan dipatuhi masyarakat desa.

Pendekatan sentralistik (top down) ini telah terbukti menunjukan kegagalannya. Berbagai program yang diperkenalkan kepada masyarakat tidak berkelanjutan, ikut terkubur bersamaan dengan selesainya proyek. Masalahnya, lembaga baru ternyata tidak mengakar di masyarakat, lembaga masyarakat asli sudah melemah atau bahkan kehilangan perannya. Untuk itu program pemberdayaan seyogyanya tidak memperkenalkan lembaga baru secara "transplantatif". Program harus berangkat dari institusi komunitas, artinya pemberdayaan adalah pengembangan atau penguatan institusi komunitas yang sudah ada.

Pemberdayaan pada dasarnya proses pembelajaran di masyarakat (learning society process). Sesuai dengan prinsip pemberdayaan, proses pendampingan, dikembangkan sejauh mungkin partsipasi masyarakat, baik dalam perencanaan, pelaksanaan sampai kepada evaluasi program. Peran pendamping sebagai fasilitator saja, yang tugasnya memberikan stimulan. Proses pengambilan keputusan tetap dilakukan oleh masyarakat itu sendiri. Hal ini dimaksudkan agar terbentuk rasa memiliki terhadap program, rasa percaya diri dan tanggung-jawab dari masyarakat. ${ }^{13}$

13. Mubyarto menawarkan suatu pendekatan pemberdayaan melalui konsep "Pohon Berkelanjutan". Secara terinci asumsi yang mendasari konsep tersebut adalah:

- Pada dasarnya keberhasilan program pemberdayaan yang mengarah kepada kemandirian berkelanjutan, berawal pada kekuatan masyarakat itu sendiri. Dengan demikian, patut dicermati potensi apa saja yang dimiliki masyarakat yang dapat dikembangkan. Potensi itulah yang akan berkembang terus seiring dengan pendampingan yang diberikan.

- Beberapa potensi yang dimiliki masyarakat sebagai "akar" bagi keberhasilan program, antara lain; motivasi, kemauan mengevaluasi diri, keyakinan pada diri sendiri, kreativitas, keswadayaan dan pengalaman-pengalaman positif. Dekembangkan sampai kemanapun, potensi ini tetap menjadi milik masyarakat dan tidak akan meninggalkan masyarakat itu sendiri.

- Pendampingan diberikan bagaikan "pupuk" yang memberikan kesempatan kepada "akar" untuk tumbuh berkembang. Pupuk dimaksud antara lain berupa nasehat, pelatihan, kewenangan lokal, teknologi, keterbukaan, yang semuanya diberikan termonitor dan tepat waktu.

- Pengembangan dan pemberdayaan organisasi masyarakat tersebut juga harus tetap memperhatikan situasi dan kondisi lingkungan eksternalnya. 
Namun demikian disadari bahwa proses pembelajaran masyarakat bukanlah pekerjaan yang sederhana dan instant. Pembelajaran merupakan suatu proses yang panjang, karena berkaitan dengan upaya pencapaian visi, baik visi individu/anggota masyarakat, juga visi bersama dari kelembagaan masyarakat yang bermaksud akan dibangun.

Studi ini akan menfokuskan pada institusi komunitas dalam mengadaptasi program dari pemerintah sebagai peluang, bukan ancaman, dengan objek studi pada Program Nasional Pemberdayaan Masyarakat di Perdesaan.

\section{METODE PENELITIAN}

Sesuai dengan tujuan studi, yaitu untuk mengkaji penguatan kelembagaan masyarakat desa dari waktu ke waktu, dengan berfokus pada Program Nasional Pemberdayaan Masyarakat di Perdesaan, maka metodologi yang digunakan adalah: (1) metode analisis isi (content analysis) dengan mengkaji berbagai dokumen, perturan, dan hasil studi terdahuludengan memperhatikan setiap periode kebijakan yang diberlakukan, (2) metode kualitatif dengan melakukan pengamatan dan wawancara dengan informan kunci untuk menggali dan memahami "makna" dari setiap kebijakan pemberdayan masyarakat desa dan kelembagaannya.

\section{Hasil Kajian dan Pembahasan}

\section{Sejarah Perkembangan Kebijakan} Perdesaan Di Indonesia

Menilik sejarahnya, desa adalah satu kesatuan masyarakat hukum (adat) yang otonom sesungguhnya telah ada jauh sebelum berdirinya negara Republik Indonesia, bahkan juga sebelum masuknya kekuatan supra desa lainnya seperti kekuasaan kerajaan, dan kekuasaan pemerintahan kolonial di masa penjajahan. Masyarakat desa telah memiliki sistem kelembagaan "otonom" dan "asli", dibangun melalui proses kontrak sosial komunitas lokal, dalam suatu tatanan kelembagaan masyarakat adat. Tatanan kelembagaan tersebut terus menerus diperbaiki melalui suatu kesepakatan internal masyarakat sejalan dengan perkembangan tingkat peradaban serta tekanan dan tuntutan perubahan dari lingkungannya.

Pada masyarakat tertutup (atau bermukim di wilayah pedalaman/remote area), tatanan kelembagaan masyarakat desa (adat) yang "asli" masih dapat diamati keberadaannya. Umumnya tatanan kelembagaan tersebut menyatu dan menempatkan "lingkungan alam" sebagai variabel determinan dalam sistem pengaturan kelembagaan masyarakat adat tersebut. Ketergantungan bagi kelangsungan hidup masyarakat terhadap alam sangat tinggi, sebagai "satu-satunya" 
sumber mata pencaharian dan penghidupan, sehingga eksploitasi terhadap alam dilakukan secara hatihati dan dijaga kelestariannya. Berbagai kajian antrolopologi mengajarkan kepada kita tentang model sistem kelembagaan "tradisional" masyarakat adat yang menyatu dan menjaga keseimbangan kehidupannya dengan alam. Aturan kelembagaam masyarakat adat "tradisional" sangat kondusif bagi terjaganya kelestarian alam, yang dikenal sebagai kearifan lokal. Sistem kelembagaan tersebut di atas tidak sepenuhnya dapat ditemukan lagi pada masyarakat terbuka.

Masuknya kekuatan supra desa, diawali dengan masuknya kekuasaan raja-raja (jaman kerajaan), telah meletakan model patronisasi sistem kekuasaan kerajaan ke dalam kelembagaan desa. Pola patronisasi kekuasaan supra desa terhadap sistem kelembagaan masyarakat desa terus berlangsung sampai pada jaman pemerintahan kolonial Belanda, dan semakin diperkuat pada masa peme- rintahan orde baru. Kebijakan yang dikembangkan pada jaman kolonial Belanda, misalnya, ditandai oleh semangat pengendalian pemerintahan pada negara jajahan pada masa sebelum tahun 1903: (lihat Bhenyamin Hoesein, 1996):

Sebelum tahun 1903, organisasi Hindia Belanda sangat tersentralisasi (gecentraliseerde geregeerd land). Dianutnya sistem organisasi demikian didasarkan pada pendapat bahwa dalam wilayah yang sebagian besar rakyatnya terjajah dan bersifat majemuk (highly fragmented), kepentingan negara hanya dapat ditegakan oleh pemerintah yang sangat tersentralisasi dengan mengandalkan pada kekuatan birokrasi. Sebagai penghalusan sentralisasi kemudian dijalankan dekonsentrasi dengan cara membentuk wilayah(daerah) administrasi yang sangat hirarkhis untuk keperluan penetrasi politik. ${ }^{14}$

Kebijakan kolonial tersebut, pada masa Orde Baru selanjutnya diaptasi

14 Bhenyamin Hoesin, dalam artikelnya tentang Memutar Roda Desentralisasi; Dari efesiensi ke Demokrasi, Majalah PRISMA, 4 April 1995. Tulisan tersebut dipetik dan diringkas dari Pidato pengukuhan sebagai Guru Besar tetap Ilmu Administrasi Negara Fisip UI, Jakarta 18 Nopember 1995. Dalam masa orde baru pembentukan Daerah Otonom selalu berpasangan (overlapping) dengan wilayah administrasi. Bahkan hirarkhi wilayah administrasi lebih banyak dari Daerah Otonom, yaitu mulai dari tingkat Propinsi, Keresidenan, Kabupaten/ Kotamadya, Kewedanaan, Kecamatan, kelurahan. Sementara Daerah Otonom terdiri dari Daerah Popinsi dan Daerah Kabupaten/Kotamadya dengan didudukan dalam struktur hirarkhi pemerintahan Tingkat I dan Tingkat II. Desa sebagai pemilik otonomi asli didudukan dan di bawah hirarkhi kecamatan. 
ke dalam UU no.5/1979, pada bagian penjelasan no. 4 sebaagai berikut; “....pemerintahan desa yang sekarang ini bentuk dan coraknya masih beraneka ragam, yang kadang-kadang merupakan hambatan untuk pembinaan dan pengendalian yang intensif .....". Karakter sentralistik ini diperkuat melalui penataan struktur pemerintahan desa dengan menempatkan Kepala Desa sebagai "penguasa tunggal". Walaupun di luar Pemerintah Desa dibentuk Lembaga Musyawarah Desa (LMD), namun karena jabatannya Kepala Desa menjadi Ketua LMD (ex officio). Demikian pula dengan LKMD (Lembaga Ketahanan Masyarakat Desa), Ketua dijabat oleh Kepala Desa (ex officio), Ketua I dari unsur tokoh masyarakat, Ketua II dijabat istri Kepala Desa selaku Ketua Tim Penggerak PKK. Kebijakan yang telah ditransplantasikan selama lebih dari 20 tahun nampak jelas menjadi instrumen pemerintah pusat yang sentralisitik. Hal ini tentunya tidak menguntungkan bagi pengembangan otonomi (masyarakat) desa. Akibat terlalu lama diberlakukannya kebijakan tersebut, Tim Lapera menemukan beberapa prasangka yang berkembang di kalangan masyarakat desa, dengan intisari temuannya sebagai berikut;

1. Rakyat bodoh. Posisi rakyat yang dimarjinalisasi pada dasarnya telah menjadi sarana yang paling efektif menutup kesempatan yang dimiliki oleh rakyat. ..... hal ini menjadi tatangan berat untuk mengembalikan kepercayaan diri rakyat (dalam rangka otonomi) bahwa tidak ada manusia bodoh.

2. Ketergantungan. Apa yang dilukiskan oleh rakyat sendiri sebagai "kebodohan" terkadang menjadi sarana untuk "bersembunyi". Ini merupakan kendala besar untuk membangkitkan kemandirian mereka.

3. Pemerintah adalah hukum. Pemerintah dapat menentukan mana yang baik dan yang buruk, yang boleh dan yang tidak boleh. Ini merupakan kendala untuk menumbuhkan inisiatif dan motivasi masyarakat. Seringkali terlontar pernyataan; apakah sudah ada ijin, apakah tidak bertentangan dengan hukum atau kebijakan pemerintah, dst.

4. Warga pemerintah. Akibat dari kesadaran bahwa pemerintah adalah hukum, masyarakat berada dalam kondisi menempatkan dirinya bukan sebagai warga negara, tetapi sebagai warga pemerintah. Masyarakat bekerja berdasarkan instruksi pemerintah tanpa tahu secara jelas kemanfaatannya bagi mereka. Mis; persiapan 17-an, dst.

5. Mitos ekonomi dan anti politik. Proses yang penuh dengan represi telah menempatkan rakyat menjadi pihak yang seakan-akan (dan dalam kenyataan) tidak memiliki hak untuk ambil bagian dalam politik. ......wilayah rakyat hanyalah ekonomi. 
6. Legalitas mengalahkan legitimasi. .... lebih penting disetujui oleh pemerintah (legalitas) ketimbang adanya dukungan nyata dari rakyat (legitimasi). ${ }^{15}$

Berbagai studi terdahulu menginformasikan bahwa telah terjadi beberapa kesenjangan sebagai akibat dari berbagai kegiatan program pemerintah yang justru (tujuan utamanya) dimaksudkan untuk memperbaiki tingkat kesejahteraan masyarakat luas, khususnya masyarakat desa. ${ }^{16}$ Karakter sentralistik program Pemerintah di masa lalu dengan titik berat pada pertumbuhan dan peningkatan kesejahteraan ekonomi semata, ${ }^{17}$ justru kontraproduktif bagi terbangunnya kemandirian dan keberdayaan kelembagaan (otonomi) masyarakat desa. Misalnya hasil studi
Tjondronegoro menyatakan bahwa program-program pemerintah seperti BIMAS dan berbagai IMPRES dilaksanakan di bawah pamong desa (perangkat desa), sedangkan pengawasan dari rakyat desa sudah melemah karena lembaga-lembaga adat dan lembaga sosial sudah berkurang fungsinya. ${ }^{18}$ Pamong desa dalam konteks itu bukan lagi bertindak sebagai pemimpin lokal yang berpihak kepentingan dan aspirasi masyarakat desa, tetapi umumnyajustrumengawal kebijakan sentralistik Pemerintah Pusat. Potret ini dapat disimak dalam hasil penelitian disertasi Hans Antlov, bahwa terjadi patronisasi kepemipinan lokal masyarakat desa oleh negara (baca Pemerintah Pusat) ${ }^{19}$ sehingga tatanan kelembagaan masyarakat lokal memudar, digantikan oleh kelembagaan yang diseragamkan oleh

15. Tim LAPERA, Otonomi Versi Negara, Lapera Pustaka Utama, Cetakan Pertama, Yagyakarta, Oktober 2000.

16. Berdasarkan data Ditjen PMD, Departemen Dalam Negeri RI bahwa pada tahun 2000 jumlah desa di Indonesia sebanyak 68.988 desa, atau sekitar $70 \%$ penduduk tinggal di kawasan pedesaan, sehingga merupakan suatu keniscayaan bahwa titik berat program atau kebijakan pemerintahan diarahkan bagi peningkatan kesejahteraan masyarakat desa.

17. Sejak tahun 1970-an muncul pandangan bahwa proses perkembangan dan perubahan sosial dapat didorong, dipercepat, dan diarahkan oleh organisasi-organisasi yang sengaja dibentuk, baik yang baru maupun organisasi lama yang diperbarui (Esman, 1972; Esman \& Uphoff, 1982; Katz, dalam Eaton, 1986), dan pada masa itu paradigma pertumbuhan yang berbasis pada analisis ekonomi rasional dijadikan sebagai acuan utama (lihat misalnya Rostow, 1961; Todaro, 1977). Secara tegas, tujuan pembangunan dinyatakan sebagai penciptaan masyarakat dengan tingkat konsumsi/kemakmuran tinggi (high mass consumption).

18. Bambang Setyadi Dalam Wahono, Partisipasi Masyarakat dalam Otonomi Asli, Majalah Lesung Edisi Kedua, Juni 2000.

19. Hans Antlov, Negara dalam Desa: Patronisasi Kepemipinan Negara dalam Desa, Lapera Pustaka Utama, Yogyakarta, Nopember 2002. 
Pemerintah Pusat. Tatanan kelembagaan (otonom) masyarakat desa menjadi rapuh untuk mampu mengatasi persoalannya sendiri secara mandiri dan berkelanjutan. Dalam jangka panjang, keberhasilan dalam pembangunan bagi peningkatan kesejahteraan ekonomi menjadi kehilangan maknanya, karena dilain pihak telah menciptakan ketergantungan masyarakat kepada Pemerintah yang justru menggerogoti keberhasilan yang telah dicapai.

Sebagai koreksi terhadap berbagai kelemahan dan keterbatasan program Pemerintah di masa lalu, akhir-akhir ini dikembangkan suatu program yang berbasis pada pemberdayaan masyarakat dan kelembagaannya. Program tersebut antara lain; P2KP (Program Pemberdayaan Masyarakat Perkotaan) dan PPK (Program Pembangunan Kecamatan). P2KP menfokuskan pada penguatan kelembagaan masyarakat di tingkat kelurahan (atau desa yang sudah bercirikan perkotaan), sementara PPK menitikberatkan pada pemberdayaan masyarakat dan kelembagaannya di tingkat desa dan antar desa. ${ }^{20}$ Khusus PPK, terdapat suatu niat yang kuat untuk mengaktualisasikan kembali potensi lokal yang terpendam melalui program pemberdayaan masyarakat dan peningkatan good governance.

Kebijakan ini merupakan koreksi terhadap sistem pemerintahan masa lalu dengan kerakter sentralistik serta telah melahirkan krisis yang berkepanjangan. Perubahan yang terlihat menonjol dari kebijakan baru tersebut adalah pada penyelenggaraan desentrasliasi otonomi baik di Pemerintah Daerah (Kabupaten dan Kota) ataupun Pemerintah Desa. Perubahan kebijakan di Pemerintah Daerah yaitu adanya penyerahan kewenangan yang luas dalam menyelenggarakan kegiatan pelayanan publik dalam bidang pemerintahan, pembangunan, dan kemasyarakatan agar sesuai dengan kebutuhan dan karekatristik lokal. Tujuannya lainnya adalah untuk mengaktualkan potensi dan kemandirian Daerah dalam penyelenggaraan pelayanan publik tersebut.

Sementara itu, perubahan kebijakan dalam sistem pemerintahan Desa adalah adanya pengakuan (kembali) terhadap "hak otonomi asli" di Desa. Kebijakan tersebut adalah UU 22/1999 kemudian diperbaiki menjadi UU 32/2004, dalam kebijakan tersebut pengertian desa atau apa yang disebut dengan nama lain, adalah kesatuan masyarakat hukum yang memiliki

20. Pengembangan kelembagaan amtar desa se kecamatan dimaksudkan untuk meningkatkan bargaining position desa-desa terhadap kekuatan supra desa, khususnya kabupaten. 
kewenangan untuk mengatur dan mengurus kepentingan masyarakat setempat berdasarkan asal-usul dan adat istiadat setempat yang diakui dalam sistem pemerintahan nasional dan berada di daerah kabupaten. ${ }^{21}$ Konsep desa dalam definisi tersebut bersifat generik, artinya istilah yang digunakan dapat menggunakan nama lain sesuai dengan kesepakatan (asal usul sejarah) dan aspirasi yang berkembang di warga masyarakat. Misalnya, beberapa Desa di Kabupaten Solok, Sumatera Barat mengupayakan untuk kembali kepada sistem pemerintahan Nagari, dan menghidupkan kembali lembaga adat yaitu Majelis Tungku Tigo Sajarangan. Istilah yang digunakan bukan desa, tetapi nagari. Demikian pula isi otonomi pun sejauh mungkin mengadaptasi kekhasan dari desa yang bersangkutan, mengingat bahwa otonomi desa merupakan otonomi asli. Menurut Bambang Setyadi (PMD-Depdagri) bahwa otonomi daerah lebih merupakan "pemberian" kewenangan dari pusat kepada Daerah untuk mengelola wilayahnya, tidak termasuk desa. Desa tidak menerima otonomi, tetapi secara otonomtis desa mempunyai otonomi asli. ${ }^{22}$
Sejalan dengan semakin menguatnya isu tentang good governance dan civil society, muncul kembali kesadaran bahwa kualitas pelaksanaan otonomi desa sangat dipengaruhi oleh terbangunnya partisipasi dan keswadayaan (kemandirian) masyarakat desa. Logikanya, ketika sumberdaya yang dimiliki pemerintah semakin terbatas, sementara tuntutan dan kebutuhan (pelayanan publik) dari warga masyarakat semakin meningkat, maka partisipasi warga memegang peranan penting. Namun kebijakan yang selama ini diterapkan tidak mendukung bagi terbangunnya partisipasi masyarakat. Sebagaimana hasil studi Tim LAPERA bahwa kebijakan sentralistik yang berlangsung lama telah memperlemah kemandirian dan menciptakan ketergant ungan bagi masyarakat desa. ${ }^{23}$

Kesadaran semakin menguat setelah krisis hebat menimpa Indonesia pertengahan tahun 1998. Diperkenalkan berbagai program pemberdayaan dengan tujuan menata dan mengaktifkan kembali institusi komunitas, yang selama ini kurang berfungsi (iddle capacity). Tujuannya agar potensi (energi sosial) mereka teraktualisasikan secara optimal

21. Berada di daerah kabupaten, karena kawasan pedesaan mempunyai kegiatan utama pertanian yang juga sebagai ciri kabupaten, berbeda dengan perkotaan tidak digunakan istilah desa tetapi kelurahan.

22. Dalam, Wahono, op cit, 2000.

23. Lihat hasil studi Tim LAPERA, op cit, 2001.

24. Lihat tulisan Heru Nurasa, Pemberdayaan Masyarakat Miskin Perkotaan, Journal Forum Inovasi dan Keperintahan yang Baik, PPs PSIA-FISIP UI, Vol 3; Juni-Agustus 2002. 
untuk dapat memecahkan persoalan mereka sendiri. ${ }^{24}$ Namun mengingat instutusi komunitas sudah melemah, sementara institusi transplantatif belum dapat sepenuhnya diterima sebagai institusi komunitas yang baru, masyakarat lokal diberi keleluasaan untuk memilih institusi yang sesuai dengan aspirasi dan kebutuhannya.

Misalnya, salah satu program pemberdayaan (P2KP) memperkenalkan istilah Badan Keswadayaan Masyarakat (BKM), sebagai institusi pengambilan keputusan tertinggi yang dipilih atau dibentuk oleh komunitas sendiri. BKM hanya nama generik saja, masyarakat memilih institusi yang ada di lingkungannya, yang dapat dipercaya untuk mengelola program. Kalau institusi yang ada tidak dapat dipercaya, maka masyarakat dapat membentuk institusi baru. Hal ini dimaksudkan untuk menghindari proses transplantasi institusi di masyarakat. Dalam perjalanannya, BKM tidak lagi sebagai nama generik, tetapi terkondisikan menjadi lembaga yang berfungsi sebagai instru-men proyek untuk mengelola dana bantuan proyek. Paradigma lama dalam pengelolaan proyek pemberdayaan dengan transplantasi institusi secara top down belum dapat dirubah secara instant. Diperlukan strategi pemberdayaan yang tepat agar dapat terbangun suatu lembaga komunitas yang mandiri untuk mengatasi persoalannya sendiri.

Penguatan Kapasitas Kelembagaan Masyarakat Desa melalui Program Nasional Pemberdayaan Masyarakat di Perdesaan

Pendekatan partisipatif bagi program-program pembangunan di perdesaan sebagaimana dikemukakan terdahulu, semakin populer diperkenalkan di Indonesia. Disadari bahwa partisipasi masyarakat sangat penting sebagai "substitusi" energi ketika sumberdaya Pemerintah semakin terbatas, sementara tuntutan masyarakat akan pelayanan publik semakin meningkat, baik dari segi kualitas maupun kuantitas.

Permasalahan akan rendahnya partisipasi masyarakat ini sangat dirasakan pasca krisis ekonomi berkepanjangan semenjak pertengahan tahun 1997. Ketika sumberdaya pemerintah mengalami penurunan drastis untuk menyelenggarakan pelayanan publik dan pembangunan, sementara sumberdaya masyarakat sebagai potensi lokal tidak dapat dimanfaatkan dengan baik (iddle capacity). Kebijakan di masa lalu telah terlalu lama membiarkan energi masyarakat menjadi iddle, sehingga diperlukan berbagai program untuk mengembalikan potensi masyarakat sebagai kapasitas lokal. Program Nasional Pemberdayaan Masyarakat (PNPM) Mandiri Perdesaan sebagai salah satu kebijakan Pemerintah yang 
bertujuan membangun kembali partisipasi masyarakat sebagai kapasitas lokal. Kebijakan PNPM Mandiri Perdesaan itu sendiri merupakan pengembangan atas Program Pengembangan Kecamatan (PPK) yang dinilai berhasil dalam program pembangunan perdesaan. Kedua program itu sendiri, merupakan perbaikan atas keterbatasan dari program pembangunan perdesaan terdahulu, utamanya IDT dan P3DT.

Secara konseptual kebijakan PNPM Mandiri Perdesaan memiliki komitmen yang sangat kuat untuk membangun kembali partisipasi masyarakat desa, dengan memberikan ruang yang sangat luas kepada masyarakat untuk berpartisipasi dalam setiap tahapan kegiat an pembangunan, mulai dari perencanaan, pelaksanaan (implementasi), evaluasi dan pemanfaatan dan pemeliharan (operation and maintanance) hasil kegiat an (lihat manual PNPM Mandiri Perdesaan, 2008).

Dari kebijakan PNPM Mandiri Perdesaan, bahwa peran masyarakat dalam pembangunan perdesaan dirancang untuk lebih optimal didayagunakan, dan hal ini berbeda jauh apabila dibandingkan dengan program terdahulu bahwa pelaku utama program adalah aparat. Dalam PNPM Mandiri Perdesaan terdapat sinergi peran di antara para stakeholders pembangunan di perdesaan (pemerintah, masyarakat, dan dunia usaha) sebagai pelaku program. Satu hal yang unik dari PNPM Mandiri Perdesaan adalah didorongnya MAD (Musyawarah Antar Desa) sebagai lembaga keputusan di tingkat kecamatan (antar desa). Tujuan MAD adalah menghimpun sinergitas potensi antar desa, serta desa-desa diharapkan akan memiliki posisi tawar(bargaining position) yang lebih besar terhadap kebijakan pemerintah kabupaten. Ciri khas lainnya dari PNPM Mandiri Perdesaan yaitu didorongnya sistem nilai "kompetisi", tujuannya untuk menghapuskan image lama bahwa program adalah bagi-bagi dana pembangunan secara cuma-cuma. Sistem nilai kompetisi dimaksud bahwa desa-desa untuk memperoleh dana program harus mampu menghasilkan proposal kegiatan yang baik dan layak untuk didanai oleh program.

Karakter kebijakan PNPM Mandiri Perdesaan nampak jelas berkeinginan untuk melakukan perubahan mendasar (secara reformis) terhadap sistem lama dalam pengelolaan pembangunan di perdesaan. Dalam rangka mendukung proses reformasi secara optimal, PNPM Mandiri Perdesaan mengalokasikan dana program (block grant) dalam jumlah relatif besar untuk setiap kecamatan, dengan ketentuan setiap desa menyerap dana program maksimum sebesar Rp 100 juta. Sumber utama pembiayaan program berupa pinjaman lunak (soft loan) dari Bank Dunia dan dana partisipasi (cost sharing) dari Pemda Kabupaten, dengan memilih lokasi 
kecamatan yang memiliki banyak desa miskin. Besaran dana partisipasi Pemda Kabupaten sebesar 20\% dari dana program. Dana program berupa block grant bagi masyarakat Desa diarahkan sebagai dana stimulan bagi kegiatan pembangunan masyarakat desa-desa dalam satu kecamatan. Asumsinya bahwa dana program saja tidak memadai untuk membiayai kegiatan pembangunan pada desa miskin, sementara partisipasi masyaralat sebagai sumberdaya lokal dalam posisi tidur (iddle capacity). Artinya, bahwa dana program PNPM Mandiri Perdesaan ditujukan untuk mengaktualisasikan partisipasi masyarakat sebagai sumberdaya potensial. Sumberdaya tersebut didayagunakan secara optimal melalui suatu model kelembagaan yang dapat memberikan ruang yang luas kepada stakeholders non pemerintah untuk ikut ambil bagian dalam setiap tahapan proses pembangunan, mulai dari tahap formulasi, implementasi, evaluasi, dan pemanfaatan hasil-hasilnya.

Pada awal pelaksanaan program PNPMMandiri Perdesaan menunjukan bahwa tingkat partisipasi masyarakat desa cukup signifikan. Namun, pada tahun-tahun berikutnya menunjukan kecenderungan adanya penurunan partisipasi dalam program pembangunan perdesaan, baik ketika rancangan programnya masih bernama program Pengembangan Kecamatan (PPK), maupun setelah berganti nama menjadi PNPM Mandiri Perdesaan (lihat Gambar I.1). Berdasarkan informasi yang diperoleh dari hasil wawancara dengan berbagai pelaku program, bahwa partisipasi masyarakat sangat tinggi diawal program, dan mengalami penurunan pada tahun-tahun berikutnya. Hal ini disebabkan bahwa diawal program tersedia sumberdana yang "besar", sehingga menarik minat masyarakat desa untuk berlomba meraih dana tersebut. Selanjutnya, penurunan partisipasi terjadi ketika dana tersebut sudah diperoleh.

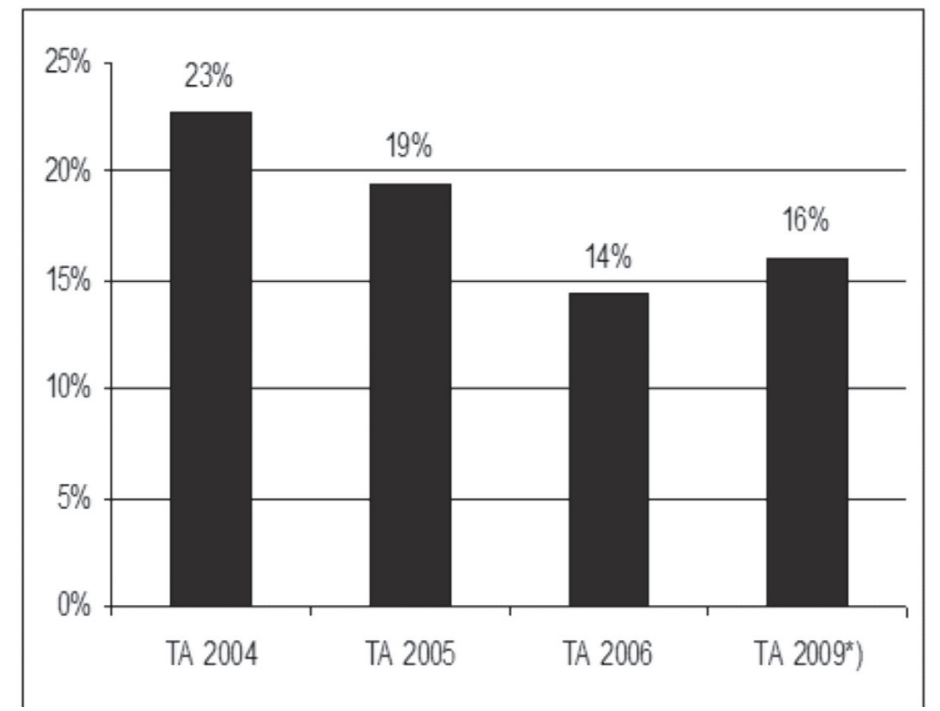

Sumber: Sekretariat Nasional PPK Ditjen PMD Depdagri, 2007

*) Laporan RMC PNPM Mandiri Perdesaan Prop Jabar, April 2009

Gambar 1.1

Perkembangan Partisipasi

Masyarakat Desa dalam Program

PPK di Jawa Barat 
Gambaran empiris tentang terjadinya penurunan partisipasi ini mengindikasikan bahwa upaya-upaya perubahan secara fundamental melalui kebijakan PNPM Mandiri Perdesaan masih menghadapi beberapa permasalahan yang perlu ditemukan akar masalahnya. Berdasarkan hasil kajian lapangan serta telaah dokumen, dapat dikemukakan beberapa faktor yang menyebabkan penurunan partisipasi masyarakat dalam program PNPM Mandiri Perdesaan. Pertama, program pembangunan perdesaan di masa lalu yang bernuansakan charity, yaitu sebagai kegiatan "bagi-bagi" kue pembangunan semata, telah membentuk sistem nilai (mind-set) yang keliru di kalangan masyarakat perdesaan. Masyarakat sudah terbiasa menerima bantuan program dengan cara mudah tanpa harus kerja keras, sehingga sudah terbentuk sikap ketergantungan terhadap bantuan pemerintah. Sistem nilai demikian tentunya tidak mudah untuk dirubah secara instant. Program Nasional Pemberdayaan Masyarakat di perdesaan melalui sistem kompetisi telah mempu merubah pola pikir dan pola perilaku lama dengan mengintrodusir sistem nilai kompetisi. Masyarakat didorong untuk membentuk kelompok, dan membuat proposal terbaik untuk berkompetisi dengan kelompok lainnya. Melalui sistem nilai kompetisi ini telah mampu merubah pola pikir dan pola perilaku lama, yaitu bahwa hanya kelompok yang mampu membuat proposal terbaik saja yang mendapatkan bantuan program untuk didanai kegiatan proposalnya.

Kedua, bahwa pada masa ORBA sistem nilai program pembangunan perdesaan masih sangat kuat dipengaruhi oleh nilai-nilai charity, serta model kebijakan yang sentralistik, sehingga desain kelembagaan pembangunan menuntut peran pemerintah yang kuat, karena mengasumsikan masyarakat sebagai pihak lemah (lihat Hans Antlov, 2002). Setting kelembagaan pembangunan perdesaan pada masa itu dikendalikan secara terpusat, dengan menempatkan Kepala Desa sebagai penguasa tunggal agar mudah dikendalikan oleh Pemerintah Pusat (lihat hasil penelitian Tim Lapera). Dengan setting kelembagaan demikian, peran serta masyarakat dalam program pembangunan lebih bersifat "mobilisasi", sementara peran pemerintahan desa sangat dominan (goverment centre). Pasca krisis, ketika sumberdaya Pemerintah sangat terbatas, partispasi masyarakat didutuhkan sebagai substitusi energi bagi pemerintah. Permasalahannya, untuk mengaktualisasikan kembali partisipasi masyarakat sebagai energi lokal, sistem kelembagaan PNPM Mandiri Perdesaan berbasis governance system masih harus berhadapan dengan sistem pemerintahan desa dengan karakter kelembagaan yang sentralistik.

Ketiga, sistem dan prosedur program pembangunan perdesaan yang berbasis pembinaan sudah tidak 
sesuai lagi dengan semangat good governance, serta secara faktual justru telah menciptakan ketergantungan masyarakat Sementara itu sistem dan prosedur PNPM Mandiri Perdesaan yang berfokus sebagai agen pembaharuan, sebagai motivator dan fasilitator bagi berkembangnya swadaya serta meningkatnya kompetensi dan produktivitas masyarakat dan dunia usaha, nampaknya sejalan dengan tujuan untuk menghidupkan kembali partisipasi masyarakat. Kendalanya adalah bahwa sistem dan prosedur program belum dapat berjalan secara otomatis, tetapi masih memerlukan pengawasan eksternal dari para pembina (konsultan).

Terakhir, bahwa program pembangunan perdesaan dari pola mobilisasi menuju kepada pelibatan peran secara sinergis para stakeholders pembangunan (aparat, masyarakat, dan dunia usaha) masih belum berjalan optimal. Aparat pemerintah yang sudah terbiasa memerintah dengan pola pembinaan, tidak mudah untuk mengubah kompetensinya menjadi mitra masyarakat dalam melaksanakan program pembangunan perdesaan. Demikian juga sebaliknya, masyarakat yang tadinya berperan sebagai objek saja, sekarang harus berperan sebagai subjek aktif sebagai dalam pembangunan.

\section{PENUTUP}

Di masa lalu, potret kelembagaan masyarakat desa tradisional, dengan sistem nilai gotong royong, telah terbukti berperan signifikan dalam menyelesaikan persoalan publiknya secara mandiri. Pola kelembagaan ini juga seringkali disebut sebagai kearifan lokal yang diperkuat dan diaktualisasikan kembali melalui Program Nasional Pemberdayaan Masyarakat Perdesaan. Pendekatan yang digunakan untuk mengembalikan kemandirian masyarakat desa tersebut dengan memberikan stimulan melalui pemberian bantuan dana dan pendampingan/fasilitasi program.

Hasil studi menunjukan bahwa Program Nasional Pemberdayaan Masyarakat di Perdesaan telah mampu mengaktualisasikan partisipasi masyarakat sebagai sumberdaya lokal yang potensial untuk menyelesaikan permasalahan publiknya secara mandiri dan berkelanjutan. Sisten nilai program, yaitu kompetisi, telah mampu merubah pola pikir dan pola perilaku masyarakat dan aparat terhadap program dari pola charity menuju pola pemberdayaan.

\section{DAFTAR PUSTAKA}

Wahono. 2000.Partisipasi Masyarakat dalam Otonomi Asli. Majalah Lesung Edisi kedua, Jakarta, Juni.

Tjondronegoro, Gejala Organisasi dan Pembangunan Terencana dalam Masyarakat Pedesaan di Jawa (1979). Dalam Gunawan Sumodiningrat. 2001. Lembaga 
Keuangan Mikro dan Penanggulangan Kemiskinan. Makalah Lokakarya P2KP. Jakarta. 22 Mei.

Hoesin, Bhenyamin. 1995. Memutar Roda Desentralisasi: Dari Efesiensi ke Demokrasi. Majalah Prisma, 4 April.

Tim Lapera. 2000. Otonomi Versi Negara. Lapera Pustaka Utama, cetakan pertama, Yogyakarta.

Nurasa, Heru. 2002. Pemberdayaan Masyarakat Miskin Perkotaan. Journal Forum Inovasi dan Kepemerintahan yang baik, PPs PSIA FISIP UI. Vol 3. JuniAgustus.

Selznick, Philip. Foundations of the Theory of Organization. American Sociological Review, vol 13, 25-35.

Woodward, Joan. 1965. Industrial Organization: Theory and Practice. London. Oxford University Press.
Roy A. Rapaport, Ritual. 1971. Sanctity, and Cybernetics. American Anthropologist, vol 73.

Astley, W. Graham and Andrew van de Ven. 1983. Central Perspective and Debates in Organization Theory. Administrative Science Quarterly.

Pfeffer, Jeffrey. 1982. Organization and Organization Theory. London. Pitman Publishing Inc.

Hannan, Michael T. and John H. Freeman. 1985. The Population Ecology of Organization. American Journal of Sociology, vol 82, p 929-964.

Berger, Peter and Thomas Luckman. 1981. The Social Construction of Reality. England, Penguin Books Ltd.

Simon, Herbert. 1945. Administrative Behaviour. New York Macmillan.

Wuisman, JJJM. 1996. Penelitian Ilmu-Ilmu Sosial. Jakarta. Lembaga Penerbit Fakultas Ekonomi Universitas Indonesia. 